\title{
Skutki braku uwzględnienia wniosku Państwowej Komisji Wyborczej w sprawie zmian okręgów wyborczych w wyborach do Sejmu i Senatu ${ }^{1}$
}

\begin{abstract}
The consequences of the lack of complying with the National Electoral Commission's proposal on changes in electoral districts in the elections to the Sejm and the Senate: The author stated that the lack of complying with the National Electoral Commission's proposal on changes in electoral districts in the elections to the Sejm and Senate will result in an internal inconsistency of the Electoral Code with regard to elections to the Sejm. It will also cause a violation of the constitutional principle of equality in elections. On the other hand elections conducted in accordance with the legal framework without the NEC's proposal will be valid. Doubts as to the validity of the elections may arise, if the Constitutional Tribunal considers the current provisions (i.e. not-amended as the NEC suggested) unconstitutional.
\end{abstract}

Keywords: Electoral Code,Constitution, National Electoral Commission, elections

Słowa kluczowe: Kodekswyborczy, Konstytucja, Państwowa KomisjaWyborcza,wybory

\section{Przedmiot opinii}

Przedmiotem niniejszej opinii jest ocena skutków ewentualnego braku uwzględnienia wniosku Państwowej Komisji Wyborczej w sprawie zmian dotyczących okręgów wyborczych w wyborach do Sejmu i Senatu. Analizie zostanie poddany problem, czy ewentualne niewprowadzenie proponowanych przez PKW zmian: może skutkować stwierdzeniem przez Sąd Najwyższy nieważności wyborów parlamentarnych, które zostaną zarządzone w bieżącym roku².

1 Opinia prawna $w$ sprawie skutków ewentualnego braku uwzględnienia wniosku Państwowej Komisji Wyborczej w sprawie zmian dotyczacych okregów wyborczych w wyborach do Sejmu i Senatu sporządzona 25 stycznia 2019 r. na zlecenie Szefa Kancelarii Sejmu; BAS-WAKiU 102/19.

2 Pismo PKW do Marszałka Sejmu z 19 listopada 2018 r. w trybie art. $203 \$ 1$ Kodeksu wyborczego; dalej: pismo PKW. 


\section{Treść pisma PKW z 19 listopada 2018 r.}

Państwowa Komisja Wyborcza informuje, że na podstawie art. $203 \$ 1$ Kodeksu wyborczego: zobowiąana jest do przedłożenia Sejmowi wniosku w sprawie zmiany granic okręgów wyborczych i liczby posłów w nich wybieranych, jeżeli konieczność taka wynika ze zmian w zasadniczym podziale terytorialnym państwa lub ze zmiany liczby mieszkańców $w$ okręu wyborczym lub w kraju ${ }^{3}$. Wyjaśnia, że po zastosowaniu przepisów kodeksowych odnoszących się do wyznaczania podziału mandatów między poszczególne okręgi wyborcze do Sejmu: dokonała analizy zgodności liczby posłów wybieranych w okregach wyborczych do Sejmu Rzeczypospolitej Polskiej, określonej w załączniku nr 1 do Kodeksu wyborczego. Wyniki tej analizy, przedstawione $\mathrm{w}$ formie tabeli, wskazują, że zasadna jest zmiana alokacji mandatów, tj. w: okręgach wyborczych nr 9, 31, 32, 33 i 34 należy zmniejszyć o 1 liczbę wybieranych posłów, natomiast w okręgach $n r$ 3, 20, 25, 26 i 39 liczbę wybieranych posłów należy zwiększyć o 1 . W tym celu konieczna jest nowela Kodeksu wyborczego polegająca na odpowiedniej modyfikacji załącznika nr 1 zatytułowanego „Wykaz okręgów wyborczych do Sejmu Rzeczypospolitej Polskiej".

W dalszej części pisma PKW informuje, że w trybie art. $261 \S 5 \mathrm{w}$ związku $z$ art. $203 \$ 1$ Kodeksu dokonała analogicznej analizy podziału na okręgi wyborcze do Senatu. Stwierdza, że w jej wyniku należałoby, poprzez odpowiednią zmianę załącznika nr 2 Kodeksu („Wykaz okręgów wyborczych do Senatu Rzeczypospolitej Polskiej”), zwiększyć o jeden liczbę okręgów wyborczych w województwie mazowieckim oraz zmniejszyć o jeden w województwie śląskim. Ponadto PKW zwraca uwagę: na sytuację występujaca $w$ województwach podkarpackim i lubelskim. Województwo podkarpackie ma większą liczbę mieszkańców (2 111 645) i przypada mu 5 mandatów. Natomiast województwo lubelskie ma mniejsza liczbę mieszkańców (2 097 946) i przypada mu 6 mandatów. Podkreśla, że sytuacja ta nie narusza przepisów kodeksowych, „lecz budzi wątpliwości”.

\section{Podział okręgów wyborczych do Sejmu - podstawowe konsekwencje nieuwzględnienia wniosku PKW}

Uregulowane w art. 201-203 Kodeksu zasady podziału okręgów wyborczych do Sejmu, których operacjonalizację stanowi zawarty w załączniku nr 1 opis poszczególnych okręgów, stanowią konsekwencję zasady równości wyborów do Sejmu, określonej w art. 96 ust. 2 Konstytucji. Zgodnie z powszechnie aprobowanym stanowiskiem doktryny treścią tej zasady, stanowiącej szczególną postać

3 Ibidem. 
ogólnej konstytucyjnej zasady równości (art. 32 Konstytucji) ${ }^{4}$, są dwa wymogi stawiane ustawodawcy określającemu szczegóły dotyczące przeprowadzania wyborów do Sejmu. Po pierwsze, każdemu wyborcy należy przyznać taką samą liczbę głosów (aspekt formalny równości wyborów). Po drugie, każdy głos winien mieć taką samą siłę, mówiąc inaczej - wagę (aspekt materialny równości wyborów). Zastosowane przez PKW zasady wyznaczania okręgów wyborczych do Sejmu są prostą konsekwencją drugiego z powołanych aspektów. Pojęcie „takiej samej siły" głosów postrzega się bowiem jako taki sam potencjalny wpływ każdego z głosów na wynik wyborów. Tego typu stan zapewnia się w taki sposób, że tworzy się okręgi wyborcze, zachowując w każdym z nich taką samą proporcję między liczbą zamieszkujących okręg mieszkańców a liczbą przypadających na dany okręg mandatów ${ }^{5}$. W praktyce osiągnięcie w każdym z okręgów owej identycznej proporcji nie jest możliwe, na co trafnie zwrócił uwagę Trybunał Konstytucyjny w wyroku z 20 lipca 2011 r., sygn. akt K 9/1 $1^{6}$. Wspomniany mechanizm normatywny zawarty w art. 201-203 Kodeksu służy jednak temu, aby jak najbardziej się do owej „idealnej materialnej równości” zbliżyć.

W świetle powyższych uwag należy stwierdzić, że brak uwzględnienia przedstawionego przez PKW wniosku w sprawie zmiany alokacji mandatów między poszczególne okręgi wyborcze do Sejmu sprawi, iż najbliższe wybory do izby zostaną przeprowadzone w okręgach, z których część (10 z 41) będzie skonstruowana w sposób nieprawidłowy, tj. liczba przypadających nań mandatów nie będzie odpowiadać wymogowi zapewnienia we wszystkich okręgach w możliwie najpełniejszym stopniu takiej samej siły głosów. Taki stan rzeczy budzi istotne zastrzeżenia $\mathrm{w}$ świetle ustanowionej w art. 96 ust. 2 Konstytucji zasady równości wyborów do Sejmu. Co więcej, oczywiste jest, że Kodeks zostanie obarczony wewnętrzną niespójnością. Podział mandatów wskazany w załączniku nr 1 nie będzie bowiem skorelowany z zasadami tworzenia okręgów zawartymi w art. 201-203. Odnośnie do tej drugiej wady można rozważać, czy nie skutkuje ona naruszeniem konstytucyjnej zasady określoności prawa, stanowiącej jedną z tzw. zasad pochodnych drugiego stopnia zasady demokratycznego państwa prawnego (art. 2 Konstytucji). Jest to jednak kwestia dyskusyjna ${ }^{7}$.

4 Zob. np. L. Garlicki, Uwagi do art. 96 [w:] Konstytucja Rzeczypospolitej Polskiej. Komentarz, t. I, red. L. Garlicki, Warszawa 1999, s. 8.

5 Zamiast wielu zob. P. Czarny, Uwagi do art. 96 [w:] Konstytucja RP, t. II, Art. 87-243, red. M. Safjan, L. Bosek, Warszawa 2016, s. 253.

6 OTK-A ZU 2011, nr 6, poz. 61. TK stwierdził, że: [r]ówność materialna wyborów jest [...] pewnq dyrektywa, która ustawodawca powinien starać się realizować, mając świadomość, że nie jest możliwe zrealizowanie jej w pełnym zakresie.

7 Na temat zasady określoności prawa zob. np. W. Sokolewicz, M. Zubik, Uwagi do art. 2 [w:] Konstytucja Rzeczypospolitej Polskiej. Komentarz, t. I, red. L. Garlicki, M. Zubik, Warszawa 2016, s. 146-152. 


\section{Podział okręgów wyborczych do Senatu - podstawowe konsekwencje nieuwzględnienia wniosku PKW}

W odniesieniu do okręgów wyborczych do Senatu odpowiednikami wymienionych wyżej przepisów są art. 260 i art. 261 Kodeksu, a ich operacjonalizację stanowi opis poszczególnych okręgów zawarty w załączniku nr 2 Kodeksu. Tym samym brak uwzględnienia wniosku PKW w sprawie modyfikacji liczby okręgów w dwóch województwach skutkować będzie powstaniem wewnętrznej niespójności Kodeksu, analogicznej do wyżej wskazanej.

Inaczej rysować będzie się natomiast sytuacja w zakresie problemu materialnej równości wyborów. W art. 97 ust. 2 Konstytucji wśród zasad wyborów (tzw. przymiotników wyborczych) do Senatu nie wymieniono bowiem równości. Jakkolwiek taki stan rzeczy nie może być postrzegany - na zasadzie wykładni a contrario - że zamiarem ustawodawcy konstytucyjnego było zagwarantowanie „nierównych” wyborów do Senatu, to jednak nie może być mowy o obowiązywaniu w tych wyborach odnoszącego się do wyborów do Sejmu wymogu równości. Zdaniem TK, podzielanym przez doktrynę, które zostało wyrażone w powołanym wyżej wyroku o sygn. akt K 9/11, z ogólnego konstytucyjnego standardu równości (art. 32 Konstytucji) należy wywieść nakaz zastosowania w wyborach do Senatu wymogu równości formalnej, a więc, jak już wspomniano, zagwarantowania każdemu wyborcy takiej samej liczby głosów. Nie obowiązuje natomiast opisany wcześniej wymóg zachowania równości materialnej ${ }^{8}$. W konsekwencji brak korekty podziału terytorium państwa na okręgi wyborcze do Senatu zgodnie z postulatem PKW nie może skutkować zastrzeżeniami konstytucyjnymi, które zostały sformułowane w odniesieniu do okręgów wyborczych do Sejmu.

Na marginesie należy dodać, że zasygnalizowana w analizowanym piśmie sytuacja, w której w województwie podkarpackim, zamieszkałym przez większą liczbę mieszkańców, wyznaczonych jest mniej okręgów wyborczych do Senatu niż w województwie lubelskim, zamieszkanym przez mniejszą liczbę mieszkańców, wydaje się bezspornie ujawniać niefunkcjonalność kodeksowego mechanizmu tworzenia okręgów w tych wyborach. Ewentualna korekta przepisów zdaje się jednak wymagać pogłębionych rozważań, które wydają się trudne do przeprowadzenia w sytuacji zbliżających się wyborów parlamentarnych.

\section{Wpływ braku korekty okręgów wyborczych na ważność wyborów}

Przesłanki ewentualnej negatywnej weryfikacji wyborów, skutkującej ich unieważnieniem, zostały w sposób ogólny - tj. stosowany w odniesieniu do wszyst-

8 Na temat problemu równości wyborów do Senatu zob. np. P. Czarny, Uwagi do art. 9 [w:] Konstytucja RP, t. II, Art. 87-243, red. M. Safjan, L. Bosek, Warszawa 2016, s. 267. 
kich wyborów, których przebieg regulują przepisy Kodeksu wyborczego - wymienione w art. $82 \$ 1$ Kodeksu. Przepis ten stanowi, że: [p]rzeciwko ważności wyborów, ważności wyborów w okręgu lub wyborowi określonej osoby może być wniesiony protest z powodu: 1) dopuszczenia się przestępstwa przeciwko wyborom, określonego w rozdziale XXXI Kodeksu karnego, mającego wplyw na przebieg głosowania, ustalenie wyników głosowania lub wyników wyborów lub 2) naruszenia przepisów kodeksu dotyczących głosowania, ustalenia wyników głosowania lub wyników wyborów, mającego wpływ na wynik wyborów.

Treść przytoczonego przepisu wskazuje, że ewentualny brak uwzględnienia postulatów PKW zawartych $\mathrm{w}$ analizowanym piśmie formalnie nie ma wpływu na ważność wyborów przeprowadzonych na podstawie aktualnego (nieskorygowanego) stanu prawnego. Opisane wcześniej zastrzeżenia prawne, wynikające z potencjalnego braku korekty dotyczącej okręgów wyborczych do Sejmu i Senatu, odnoszą się bowiem do stanu (treści) samych przepisów Kodeksu, a także dwóch załączników. Tymczasem z art. $82 \$ 1$ Kodeksu wynika, że podstawami skutecznego protestu wyborczego mogą być, mówiąc w uproszczeniu, albo stwierdzenie popełnionego określonego przestępstwa przeciwko wyborom, albo naruszenie wybranych przepisów kodeksowych, co oznacza ich niewłaściwe zastosowanie. Nie ma tu więc mowy o wadliwości samego Kodeksu.

Mimo powyższych uwag należy zasygnalizować teoretyczną sytuację, gdy $\mathrm{w}$ toku rozpatrywania protestu wyborczego, $\mathrm{w}$ jakimś stopniu związanym $\mathrm{z}$ nieprawidłowym wyznaczeniem okręgów wyborczych, odpowiedni sąd (w przypadku wyborów do Sejmu i Senatu Sąd Najwyższy) wystąpi do TK z pytaniem prawnym (dotyczącym konstytucyjności przepisów Kodeksu regulujących wspomnianą materię), a Trybunał po materialnym rozpatrzeniu zarzutów podzieli zastrzeżenia sądu pytającego. W takim wypadku mógłby zapewne zostać podniesiony problem wpływu orzeczenia TK na ważność wyborów przeprowadzonych na podstawie niekonstytucyjnych przepisów. Trzeba jednak ponownie podkreślić, że zarysowana sytuacja jest czysto teoretyczna. Wiążą się z nią na tyle liczne wątpliwości, że warto ją jedynie zasygnalizować, nie przesądzając, czy w analizowanym przypadku - bądź jakimkolwiek innym - mogłaby ona w rzeczywistości wystąpić. Należy odnotować, że w przeszłości, jeszcze przed wejściem w życie obecnie obowiązującej Konstytucji, został podniesiony zarzut niekonstytucyjności przepisu ustawy wyborczej w proteście wyborczym dotyczącym wyborów prezydenckich, a Sąd Najwyższy odmówił jego uwzględnienia, stwierdzając, że zarzut taki nie koresponduje z podstawami prawnymi wnoszenia protestów wyborczych (nie odnosi się do naruszenia przepisów ustawy wyborczej) $)^{9}$.

9 Zob. postanowienie SN z 6 grudnia 1995 r., sygn. akt III SW 654/95, OSNP 1996, nr 2, poz. 21. 


\section{Zmiany dotyczące okręgów wyborczych w świetle tzw. ciszy legislacyjnej odnoszącej się do prawa wyborczego}

Na marginesie dotychczasowych rozważań należy dodać, że trwa okres tzw. ciszy legislacyjnej w związku z planowanymi na obecny rok wyborami do Parlamentu Europejskiego, a niebawem rozpocznie się analogiczny okres wynikający ze zbliżających się wyborów parlamentarnych. Istotą owej ciszy legislacyjnej jest, zgodnie z orzecznictwem TK, zakaz uchwalania ,istotnych zmian w prawie wyborczym" (dotyczących danego, zbliżającego się typu wyborów, nie zaś prawa wyborczego jako całości) później niż: sześć miesięcy przed kolejnymi wyborami, rozumianymi nie tylko jako sam akt głosowania, lecz także jako całość czynności objętych tzw. kalendarzem wyborczym. TK wskazuje ponadto, że: [e]wentualne wyjątki od tak sformułowanego wymiaru niedokonywania zmian w prawie wyborczym mogłyby wynikać jedynie z nadzwyczajnych okoliczności o charakterze obiektywnym ${ }^{10}$.

Prima facie kodeksowe mechanizmy korekty okręgów wyborczych, tj. przywołany w analizowanym piśmie PKW art. 203 Kodeksu, a także - odnoszący się do podziału gmin na okręgi wyborcze - art. $421 \S 1$ Kodeksu, pozostają w sprzeczności z zarysowanym wyżej standardem konstytucyjnym. Wskazują one bowiem na możliwość zmian w podziale na okręgi wyborcze na wniosek PKW nie później niż na trzy miesiące przed dniem, w którym upływa termin zarządzenia wyborów do Sejmu i Senatu (bądź, w przypadku art. $421 \$ 1$, przed upływem kadencji rad samorządowych), a zatem później niż sześć miesięcy przed pierwszą czynnością przewidzianą w kalendarzu wyborczym (którego bieg z natury rzeczy rozpoczyna się wraz z zarządzeniem wyborów). Wydaje się jednak, że powołane przepisy Kodeksu nie tyle umożliwiają „przełamanie” wspomnianej ciszy legislacyjnej (co prowadziłoby do wniosku, że są niekonstytucyjne), lecz nie stoją z nią w sprzeczności. Ratio legis owej instytucji prawnej jest bowiem wykluczenie możliwości dokonywania „koniunkturalnych” (motywowanych politycznie) zmian prawa wyborczego, mających na celu zwiększenie szans na sukces wyborczy tych frakcji politycznych, które spowodowały uchwalenie tych zmian. Tymczasem analizowany mechanizm korekty okręgów wyborczych z inicjatywy PKW nie jest obarczony ową „politycznością”, zarówno z uwagi na obecny status prawny Państwowej Komisji Wyborczej, jak i na oczywistą przyczynę tych zmian, tj. zaistniałe „między” kolejnymi wyborami migracje ludności. Wspominając o dodatkowym aspekcie, jaki stanowi odnoszące się do analizowanych przepisów Kodeksu domniemanie konstytucyjności, wydaje się, że ich zastosowanie może

10 Zob. orzeczenie TK z 3 listopada 2006 r., sygn. akt K 31/06, OTK-A ZU 2006, nr 10, poz. 147, a także późniejsze wyroki: orzeczenie TK z 28 października 2009 r., sygn. akt Kp 3/09, OTK-A ZU 2009, nr 9, poz. 138, oraz przywołany wcześniej wyrok w sprawie o sygn. akt K 9/11. 
zostać uznane za przykład „nadzwyczajnej okoliczności o charakterze obiektywnym", które uzasadnia dokonanie istotnej zmiany prawa wyborczego z niezachowaniem wymogu ciszy legislacyjnej.

\section{Podsumowanie}

- Podstawowym skutkiem braku uwzględnienia wniosku Państwowej Komisji Wyborczej w sprawie zmian dotyczących okręgów wyborczych w wyborach do Sejmu i Senatu będzie powstanie wewnętrznej niespójności Kodeksu wyborczego. Podział mandatów między poszczególne okręgi wskazany w załącznikach nr 1 (wybory do Sejmu) oraz nr 2 (wybory do Senatu) nie będzie bowiem skorelowany z zasadami tworzenia okręgów zawartymi w art. 201-203 (Sejm) oraz art. 260 i art. 261 Kodeksu wyborczego. Można rozważać, czy wadliwość ta nie skutkuje naruszeniem konstytucyjnej zasady określoności prawa, stanowiącej jedną z tzw. zasad pochodnych drugiego stopnia zasady demokratycznego państwa prawnego (art. 2 Konstytucji). Jest to jednak kwestia dyskusyjna.

- Brak uwzględnienia wniosku PKW w zakresie okręgów wyborczych do Sejmu budzi istotne zastrzeżenia w świetle ustanowionej w art. 96 ust. 2 Konstytucji zasady równości wyborów do Sejmu. Zostałyby one przeprowadzone w sytuacji niedochowania, w najpełniejszy sposób, tzw. materialnej równości tych wyborów. - Brak uwzględnienia postulatów PKW formalnie nie ma wpływu na ważność wyborów przeprowadzonych na podstawie aktualnego (nieskorygowanego) stanu prawnego. Zastrzeżenia prawne wynikające z potencjalnego braku korekty dotyczącej okręgów wyborczych do Sejmu i Senatu odnoszą się bowiem do stanu treści samych przepisów Kodeksu wyborczego, a także dwóch załączników. Tymczasem z art. $82 \$ 1$ Kodeksu wynika, że podstawami skutecznego protestu wyborczego mogą być, mówiąc w uproszczeniu, albo stwierdzenie popełnionego określonego przestępstwa przeciwko wyborom, albo naruszenie wybranych przepisów kodeksowych, co oznacza ich niewłaściwe zastosowanie. Nie ma tu więc mowy o wadliwości samego Kodeksu.

- Mimo powyższej tezy należy zasygnalizować czysto teoretyczną sytuację, gdy $\mathrm{w}$ toku rozpatrywania protestu wyborczego, w jakimś stopniu związanym z nieprawidłowym wyznaczeniem okręgów wyborczych, odpowiedni sąd (w przypadku wyborów do Sejmu i Senatu Sąd Najwyższy) wystąpi do TK ze stosownym pytaniem prawnym, a Trybunał po materialnym rozpatrzeniu zarzutów podzieli zastrzeżenia sądu pytającego. W takim wypadku mógłby zapewne potencjalnie zostać podniesiony problem wpływu orzeczenia TK na ważność wyborów przeprowadzonych na podstawie niekonstytucyjnych przepisów. Zarysowana teoretyczna sytuacja jest jednak obarczona wieloma zasadniczymi wątpliwościami co do możliwości jej ewentualnego wystąpienia w praktyce. Przykładowo należy odnotować, że w przeszłości, jeszcze przed wejściem w życie obecnie obowią- 
zującej Konstytucji, wystąpił przypadek podniesienia zarzutu niekonstytucyjności przepisu ustawy wyborczej w proteście wyborczym dotyczącym wyborów prezydenckich, a Sąd Najwyższy odmówił jego uwzględnienia, stwierdzając, że zarzut taki nie koresponduje z podstawami prawnymi wnoszenia protestów wyborczych.

\section{Bibliografia}

Czarny P., Uwagi do art. 9 i 96 [w:] Konstytucja RP, t. II, Art. 87-243, red. M. Safjan, L. Bosek, Warszawa 2016.

Garlicki L., Uwagi do art. 96 [w:] Konstytucja Rzeczypospolitej Polskiej. Komentarz, t. I, red. L. Garlicki, Warszawa 1999.

Sokolewicz W., Zubik M., Uwagi do art. 2 [w:] Konstytucja Rzeczypospolitej Polskiej. Komentarz, t. I, red. L. Garlicki, M. Zubik, Warszawa 2016. 